\title{
A systematic review of romantic jealousy in relationships
}

\section{Una revisión sistemática de los celos románticos en la relación de pareja}

\author{
Nancy Consuelo Martínez-León \\ Universidad de Granada, España \\ Universidad El Bosque, Colombia \\ Juan José Peña \\ Universidad El Bosque, Colombia \\ Hernán Salazar \\ Universidad El Bosque, Colombia \\ Andrea García \\ Universidad El Bosque, Colombia \\ Juan Carlos Sierra
}

Centro de Investigación Mente, Cerebro y Comportamiento (CIMCYC), Universidad de Granada, España

Rec (27 de febrero de 2017) Acept (2 de mayo de 2017)

\begin{abstract}
Romantic jealousy is a complex emotion activated by a real or perceived threat to the relationship. Romantic jealousy is an important phenomenon in public health, as it brings consequences for the subject, the couple and the rival, even to the point of death. This theory-based study performed a systematic review of the research published in major international databases and platforms, as of December, 2016. The results of 230 studies that met the inclusion criteria were classified in pursuance of the variables associated with jealousy: a) personal variables (differences in sex, sexual orientation, hormones / use of contraceptives, self-esteem, attachment style and use of alcohol); b) interpersonal variables (romantic love, satisfaction and violence); c) sociocultural variables (transcultural comparisons, features of the rival and social networks). Future studies, with sufficient statistical robustness, should achieve a clinical formulation that indicates the relevance and predictive power of each variable.

Keywords: Jealousy, infidelity, relationship, systematic review, spousal violence.
\end{abstract}

\section{Resumen}

Los celos románticos son una emoción compleja que se activa ante una amenaza real o percibida a la relación sentimental. Constituyen un fenómeno relevante en salud pública por las consecuencias para sí mismo, la pareja y el rival, llegando incluso hasta la muerte. El presente estudio teórico realiza una revisión sistemática de investigaciones publicadas en las principales bases de datos y plataformas internacionales, hasta diciembre del 2016. Los resultados de los 230 estudios que cumplían con los criterios de inclusión fueron clasificados en función de las variables asociadas a los celos: a) personales (diferencias de sexo, orientación sexual, hormonas/uso de anticonceptivos, autoestima, estilo de apego y consumo de alcohol); b) interpersonales (amor romántico, satisfacción y violencia); y c) socioculturales (comparaciones transculturales, características del rival y redes sociales). Futuros estudios, con suficiente robustez estadística, deberán lograr una formulación clínica que indique la relevancia y el poder de predicción de cada variable.

Palabras clave: Celos, infidelidad, pareja, revisión sistemática, violencia conyugal.

\footnotetext{
Correspondence: should be addressed to Nancy Consuelo Martínez-León, Psychology Department, Universidad El Bosque. Carrera 9 No. 131 A - 02, Bogotá (Colombia), E-mail: martineznancy@unbosque.edu.co

Note: The authors would like to acknowledge the members of the research project, "Multidimensional analysis of the conduct of jealousy," of the El Bosque University and the Psychologist Natalia Caraballo, for their contributions.
} 


\section{Introduction}

Romantic jealousy is a complex affective emotion which is akin to the very human nature in intimate relationships; romantic jealousy is also indispensable for social order (Clanton, 1996). Romantic jealousy is the subject of study of human and social sciences (De Silva, 1997; Osamu, 2016) from different psychological and psychiatric currents (Pines, 1992; Soyka, Naber, \& Volcker, 1991).White (1981) states that romantic jealousy can be defined "as a complex set of thoughts, feelings and actions that follow a threat to self-esteem and / or threaten the existence or quality of the relationship. These threats are generated by the perception of a real or potential attraction between the partner and a (perhaps imaginary) rival" (p.24). Hart and Legerstee (2013) state that jealousy is a state which - depending on the context - can arouse emotions like sadness (loss), anger (treason), or fear or anxiety (loneliness).

There are different types of romantic jealousy. Buunk (1997), subdivides them into: a) reactive jealousy, caused by intimate behavior of a partner with a third party; b) anxious jealousy, focused on the possibility that the couple is sexually or emotionally involved with someone else; c) preventive jealousy, aimed at preventing intimate contact of the partner with a third party upon slight indications of interest. Pfeiffer and Wong (1989), while developing the Multidimensional Jealousy Scale, argued that jealousy can be: a) emotional jealousy - reaction to the perceived threat; $b$ ) cognitive jealousy - concerns about the involvement of the partner in infidelity c) behavioral jealousy - monitoring behaviors. The American Psychiatric Association (2013) DSM-5, classifies jealousy as follows: a) obsessive jealousy, as a "specified related disorder" of another compulsive-obsessive disorder; and (b) jealousy-type within the delusional disorder.

Romantic jealousy can become pathological, with serious consequences, when the ability to control it is lost. This may lead even to the point of killing the partner (Mužinié et al., 2003), as concluded by Harris (2003) in the meta-analysis of the literature of jealousy-driven homicides (20 reports from different countries) and the Chicago Homicide Dataset, which reported 1,361 victims between the years 1965 and 2000 , where sexual jealousy and sexual rivalry were present and the offenders accused their victims of infidelity. After the murder, 275 perpetrators committed suicide (Block \& Block, 2012).

Research on the topic has a relatively short history. Its beginnings date back to a symposium on the Convention of the American Psychological Association in 1977, where jealousy and envy were legitimized as a topic of scientific research (Salovey, 1991). However, it was not until the mid-90s that there began to emerge a large number of scientific studies analyzing jealousy and its relationship with different variables (Hart \& Legerstee, 2013). For example, the existence of sex differences based on the evolutionary hypothesis, depending on the situation of infidelity (emotional or sexual) that activates it (Bendixen, Kennair, \& Buss, 2015); the influence of sexual orientation (Alves, Pereira, Tieme, \& Otta, 2006; Dijkstra, Barelds, \& Groothof, 2013); the specific characteristics of the rival that causes jealousy (Buunk \& Dijkstra, 2015; Massar \& Buunk, 2016); transcultural comparisons (Croucher et al., 2012; Fernández, Sierra, Zubeidat, \& Vera-Villarroel, 2006; Zandbergen \& Brown, 2015); and even the relationship of jealousy with hormonal changes in estrogen in women (Cobey et al., 2012). Similarly, studies have been conducted on the way social networks (Facebook and Snapchat) may continuously incite this emotion (Halpem, Katz, \& Carril, 2017).

It is also stated that romantic jealousy is associated with more insecure and anxious attachments (Miller, Denes, Diaz, \& Buck, 2014), low self-esteem and insecurity (DiBello, Rodriguez, Hadden, \& Neighbors, 2015) and higher levels of romantic love (Swami et al., 2012). The potentially inherent elevated levels of aggression have been associated with alcohol problems (Rodriguez, DiBello, \& Neighbors, 2015), which would explain the perpetration of frequent episodes of intimate partner violence (Kar \& O'Leary, 2013; Llor-Esteban, García-Jiménez, Ruiz-Hernández, \& Godoy-Fernández, 2016; López-Ossorio, González Álvarez, Buquerín Pascual, García, \& Buela-Casal, 2017) and end up affecting satisfaction, quality and commitment in the relationship (Dandurand \& Lafontaine, 2014). The dating violence start from adolescence (Cortés-Ayala et al., 2015; Ureña, Romera, Casas, Viejo, \& Ortega-Ruiz, 2015). In turn, this has also become one of the most frequent reasons for consultation in couples' therapy.

In light of the importance of the subject from the scientific, social and public-health related viewpoints, absence of review articles - as far as is known - compiling studies of the problem, and the multiplicity of associated variables, this theory-based study undertook to synthesize the best scientific evidence available through a systematic review of the main factors involved in romantic jealousy in relationships. To this end, items were organized and grouped into three types of variables: (a) personal variables (differences in sex, sexual orientation, hormones / use of contraceptives, self-esteem, attachment style and use of alcohol); (b) interpersonal variables (romantic love, satisfaction and violence); (c) sociocultural variables (transcultural comparisons, features 
of the rival and social networks). The review was conducted by explicitly and rigorously using methods to identify, critically evaluate and synthesize the most relevant studies (Perestelo-Pérez, 2013).

\section{Method}

\section{Literature review}

A bibliography search was conducted on EBSCOEhost and ProQuest platforms, as well as the following databases: Scopus, Web of Science, PsycINFO, PsyNet, Redalyc and Science Direct. The search terms used were: "jealousy", "jealous" and in Spanish: "celos", "celotipia" - types of jealousy. The search focused on the titles of scientific papers published in English or Spanish as of December 2016, in the areas of Health Sciences and Psychology.

\section{Inclusion criteria}

The papers selected were articles wherein romantic jealousy is related with some other variable in adolescents and / or adults.

\section{Procedure}

The items are classified by variables and year of publication. Subsequently, the items that met the inclusion criteria were identified. Whenever difficulties were encountered as to compliance with the criteria, the articles were read by two reviewers and selected or ruled out by consensus. Finally, the information was recorded in a bibliographic record database.

\section{Coding the papers}

The entirety of the text of the articles selected was reviewed, and the following information was extracted: (a) author/s and year of publication; (b) methodology, identifying the study design as rated by Montero and León (2007); (c) sample - recording the number of participants, gender, sexual orientation and sample type; (d) method for evaluating romantic jealousy; (e) main results obtained. Lastly, the papers were classified in the organization variables proposed.

\section{Results}

Two hundred and thirty scientific articles published between 1978 and December 2016 were reviewed. Figure 1 illustrates the process of selecting the articles. The vast majority of articles discussed three to five variables simultaneously.

Figure 1. Flowchart of information through the different stages of the systematic review-

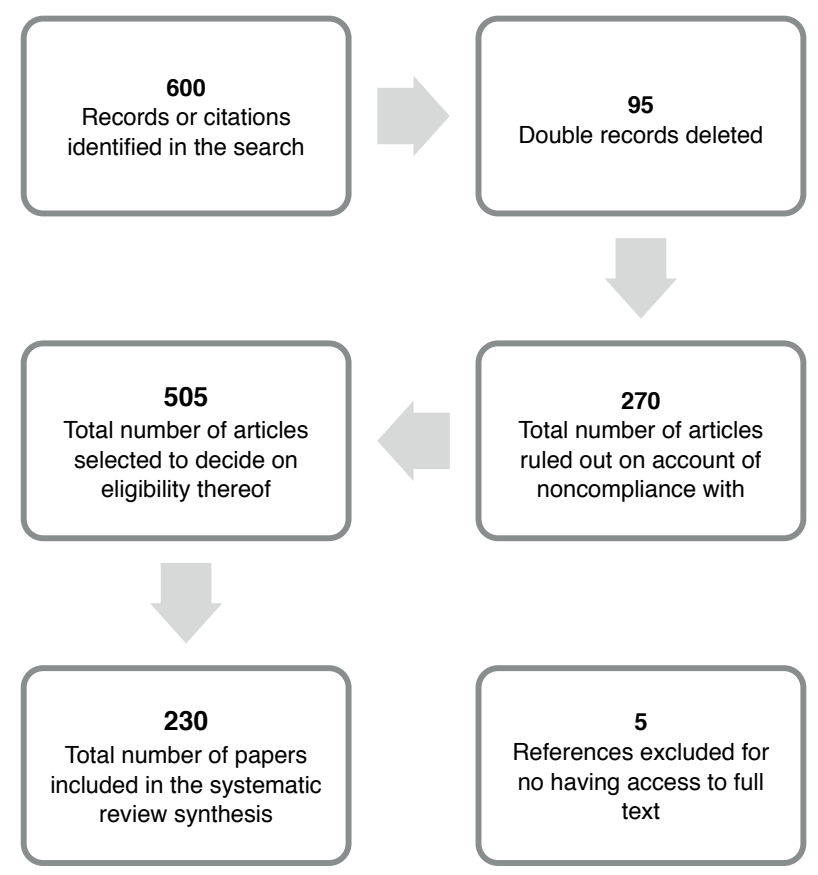

The authors with the highest production were A.P. Buunk, B.P. Buunk, P. Dijkstra, R.B. Hupka, J. Canto and C.R. Harris. The methodology used in the studies compiled was ex post facto type (71.7\%), quasi-experimental $(21.7 \%)$ and experimental $(6.5 \%)$. Over half of the studies used college student samples $(60 \%)$, followed by general population $(27 \%)$ and mixed samples of students and general population (10.4\%). The study conducted by Frederick and Fales (2016) used the largest and most diverse sample $(63,894$ people). The majority of studies measured samples of both sexes $(90.4 \%)$. Finally, the research included heterosexual participants (39.1\%), only homosexuals $(1.3 \%)$ and participants from different orientations $(10.9 \%) .48 .7 \%$ of the studies had no reports vis-à-vis this variable.

Around 40 different instruments have been used in measuring jealousy. Items derived from scales, auto standardized reports and questionnaires developed ad hoc. The most widely used instruments have been the forced choice measures based on the Infidelity Dilemmas (Buss, Larsen, 
\& Semmelroth, 1992; Buss et al., 1999), which were used in 62 studies (24.6\%); the Multidimensional Jealousy Scale (Pfeiffer \& Wong, 1989) in 21 (8.3\%); the Interpersonal Jealousy Scale (Mathes \& Severa, 1981) used in 13 studies (5.2\%); the Jealousy Scale (Buunk, 1997) used in ten studies (4\%) and the Jealousy Evoking Scenario (Dijkstra \& Buunk, $2002)$ used in seven studies (2.8\%) and 59 studies used ad hoc questionnaires (23.4\%). The main results of each of the variables are integrated below.

\section{Personal variables}

One of the most controversial and most widely researched variables in romantic jealousy is sex - namely, the difference between men and women in response to different types of infidelity (emotional or sexual infidelity), as measured in scenarios of forced choice and / or continuous measurements of the physiological responses. The evolutionary hypothesis states that men may experience more jealousy in the event of infidelity of a sexual nature, and women may do so with emotional infidelity (Bendixen et al., 2015; Buss et al., 1992). These differences can be moderated mainly by household size, income and roles (Zengel et al., 2013), processing signals of emotional and sexual infidelity (Schützwohl, 2005), previous experience of infidelity (Tagler, 2010) and sexual orientation. For example, responses both in homosexual men and women - as compared with heterosexuals of the same sex - were less intense in terms of jealousy than in scenarios that describe their partner having sex with another person (Dijkstra et al., 2013). Similarly, a higher percentage of bisexual men dating women reported being vexed more by sexual infidelity than bisexual men dating men and bisexual women (Scherer, Akers, \& Kolbe, 2013).

However, the evolutionary theory has been debated by the type of measurement used (forced choice) and the hypothetical scenario of possible infidelity, as the latter may be a measurement item that may produce errors (DeSteno, Bartlett, Braverman, \& Salovey, 2002). Studies that do not use this type of measurement found that men and women reported high levels of jealousy before sexual infidelity (Green \& Sabini, 2006; Harris, 2000).

Given the multiplicity of studies about this variable, there have been three meta-analyses. In the first meta-analysis, Harris (2003) presents 32 items and concludes - through the study of five different lines of research - that there is lack of evidence on sex differences, as there is great variability amongst men in various samples and only a minority of men reported that sexual infidelity could be worse than emotional infidelity. Harris suggests that this inconsistency in results can be better explained from a social-cognitive perspective. The second meta-analysis, presented by Carpenter (2012) with 54 articles, states that data was not consistent with the evolutionary hypothesis, as the tendency of men to respond in this way was given only in samples of American students, whilst the other data supports the social-cognitive theory. However, the third meta-analysis - made by Sagarin et al. (2012) with 40 research papers on the subject - says that sex differences in jealousy is not a forced choice item; these emerge using continuous measurements and are not limited to responses to a hypothetical infidelity (Edlund, Heider, Sherer, Farc, \& Sagarin, 2006).

Moreover, it has been reported that - at the biological level - the phases of the menstrual cycle are associated with high levels of jealousy, both in single women and women with a partner (Cobey et al., 2012). However, this differs when using contraceptive hormones during the infertile cycle; jealousy levels in women with a partner were significantly higher (Cobey, Roberts, \& Buunk, 2013). A significant negative association was also found between the 2D:4D ratio (prenatal testosterone) and emotional intensity vis-à-vis sexual infidelity (Fussell, Rowe, \& Park, 2011).

Another individual variable associated with romantic jealousy is self-esteem. Self-evaluation and self-awareness are vital in social relationships, and may be mediated by the opinion others hold about one (Leary, Tambor, Terdal, \& Downs, 1995). It is assumed that individuals with low self-esteem are more vulnerable to the experience of jealousy (Mathes, 1992). Initially, some studies found no correlation between self-esteem and romantic jealousy (Buunk, 1981; White, 1981). Later on, a negative correlation was found (Buunk, 1982; Khanchandani \& Durham, 2009; Mcintosh, 1989; Salovey \& Rodin, 1991). Most research on the subject has been conducted with explicit (controlled, conscious) measures of self-esteem, without taking into account the recent development of measures of implicit aspects (e.g. automatic or unconscious aspects) of self-esteem (DeSteno, Valdesolo, \& Bartlett, 2006). When the two measures were used, it was found that men with high levels of jealousy had explicit low self-esteem, unlike women who had high levels of implicit self-esteem (Stieger, Preyss, \& Voracek, 2012).

As for attachment style, it is recognized that the first links a person establishes in their life can be determinative of their relationships in adulthood (Bartholomew \& Horowitz, 1991). Sharpsteen and Kirkpatrick (1997) and Retana and Sanchez (2008) argue that people with different attachment styles have qualitatively different experiences of romantic jealousy. Burchell and Ward (2011) found that avoidant attachment type, along with having been victims 
of sexual infidelity, are significant predictors for men to experience pathological jealousy. Buunk (1997) found - in three measures of jealousy - that those who had anxiousambivalent attachment style were more jealous than those with an avoidant style. Also Rodriguez, DiBello, Overup and Neighbors (2015) concluded that anxious attachment moderates the association between trust and jealousy, which in turn affects satisfaction at the couple level (Dandurand $\&$ Lafontaine, 2014). In addition, women who grew up without the presence of their father reported more anxious and preventive jealousy (Brummen-Girigori, Buunk, Dijkstra, \& Girigori, 2016); and it is stated that jealousy may be mediated by differential affection - comparison with a sibling - during childhood (Rauer \& Volling, 2007) and the last children were more jealous than the firstborn (Buunk, 1997).

\section{Interpersonal variables: Relationship}

Jealousy not only affects the person who feels and expresses it, but also the partner and their emotional relationship. One of the variables researched was romantic love - understood as affiliative necessity and dependence, willingness to help and exclusivity and absorption (Rubin, 1970), which have been positively correlated with romantic jealousy (Orosz, Zoltán, Kiss, Farkas, \& Roland-Lévy, 2015; White, 1984). Retana and Sanchez (2008) found - more in women than in men - a relationship between addictive love and jealousy. Sanchez (2009) indicated that people in the infatuation (obsessive love) stage, followed by those in the stage of desperate love (harassment and persistent pursuit of interaction) are those who experience more jealousy. Swami et al. (2012) reported that the bias present in "blind love" (positive perception of physical attractiveness of the partner) in romantic love positively predicts the experience of anxious jealousy.

With regard to satisfaction and quality in the relationship, Mathes, Roter and Joerger (1982) reported that jealousy is negatively associated with marital happiness and positively associated with the frequency of altercations in the couple. High scores of jealousy, especially cognitive jealousy (Elphinston \& Noller, 2011) indicated minor adjustment, satisfaction and perception of quality in the relationship (Barelds \& Barelds-Dijkstra, 2007; DiBello et al., 2015; Khanchandani \& Durham, 2009). Mathes (1986) made two applications of the Interpersonal Jealousy Scale to the same sample of people with a period of seven years, and indicated that the effects of jealousy could be positive, in that couples were married and their love continued.
Finally, there is strong evidence in the association between (physical and verbal) violence and jealousy (Kar \& O'Leary, 2013). The latter are identified as two of the most important mediators to increase the presence of morbid / delusional jealousy (Echeburúa \& Amor, 2016); those suffering from this condition reportedly have a greater number of attempted murders against the partner (Easton \& Shackelford, 2009) and alcohol problems (Rodriguez et al., 2015; Foran \& O'Leary, 2008). DiBello, Neighbors, Rodriguez and Lindgren (2014) found that drinking was a coping strategy and a mediator between the most negative aspects of jealousy (cognitive type). Other potentially moderating factors are the cultural construction made of possessiveness, acceptance of violence in situations like infidelity and anger (Adams \& Williams, 2014; Belus et al., 2014); stress, lifestyle and social support, along with beliefs of male domination (Wang, Parish, Laumann, \& Luo, 2009). Attachment style and the level of jealousy were also associated with cyberstalking or harassment via Internet (Strawhun, Adams, \& Huss, 2013). Increased frequency of violence is indicated in distanced marriages and with young women (Stieglitz, Gurven, Kaplan, \& Winking, 2012).

\section{Sociocultural variables}

The sociocultural environment is considered a mediator of this complex interpersonal emotion, as beliefs and models can be configured, and communication networks can be established to favor or not the appearance of romantic jealousy. In a study conducted in three countries, Hupka and Zaleski (1990) argue that the problems concerning situations of jealousy and envy are similar across industrialized countries, but the particular events that cause them differ. Buunk and Hupka (1987) studied populations of seven countries, and found that - for almost all the subjects - kissing, flirting and getting involved sexually evoke a jealous response, whereas dancing, hugging and having sexual fantasies evoked no feelings of jealousy. Buunk, Angleitner, Oubaid and Buss (1996) argue that sex differences are consistent in three countries. However, Zandbergen and Brown (2015) indicate that culture in sexual infidelity could be a better predictor of jealousy than would gender. For example, Geary, Rumsey, Bow-Thomas and Hoard (1995) reported that American men expressed more anxiety regarding sexual infidelity as compared to their counterparts from China. Similar results were obtained in the comparison of Cuban men vis-à-vis Spanish men (Canto, Moscato, \& Moreno-Jimenez, 2010).

Similarly, a study was conducted on the type of rival that evokes jealousy, through the inventory of 56 characteristics 
grouped into five factors: Social Dominance, Physical Attractiveness, Physical Dominance, Seductive Behavior and Social Status (Dijkstra \& Buunk, 2002). Particularly, physical dominion in both sexes (body and face attractive, youth, height) and seductive voice (Buunk, Park, Zurriaga, Klavina, \& Massar, 2008; Buunk \& Dijkstra, 2015; O'Connor $\&$ Feinberg, 2012) can be threatening. Women are also affected by the kindness and understanding of the female rival (Ottesen, Nordeide, Andreaseen, Stronen, \& Pallesen, 2011). In cross-cultural comparisons, Buunk and Dijkstra (2015) report that no differences were found between Iraqi men and women and those from Kurdistan, whilst differences were found in the study with populations from Spain and Argentina (Buunk, Castro, Zurriaga, \& González, 2011) and Kurdistan-Iraqi people responded with much more jealousy to a variety of features of the rival than did the subjects in the study with Dutch population.

Finally, research is being conducted on the way the use of social networks like Facebook is related to jealousy, in light of the ambiguous information exposed in this realm, which feeds back images of real or imaginary situations (Muise, Christofides, \& Desmarais, 2009). In this vein, it was found that women are more likely to feel jealous as compared to men (McAndrew \& Shah, 2013). Likewise, access to (private or public) messages on Facebook can encourage jealousy, thereby affecting the emotional state, the perceived threat and the behavior of the person (Cohen, Browan, \& Borchert, 2014). In addition, the intrusion on Facebook is related to satisfaction with the partner, through cognitive jealousy and monitoring behaviors (Elphinston \& Noller, 2011). It was found that women are more involved in these activities when they feel jealous (Muise, Christofides, \& Desmarais, 2014). However, it was found that Snapchat can produce more jealousy than Facebook as compared to other social networks, thereby paving the pathway to other forms of interactions and data collection (Utz, Muscanell, \& Khalid, 2015).

\section{Discussion}

This study provides the first systematic review on romantic jealousy and potentially associated personal, interpersonal and sociocultural variables. Thus, we have collected and provided a reliable and accessible synthesis of the scientific papers published between 1978 and 2016.

The studies analyzed are mostly ex post facto, and show little diversity as to the origin of the sample-mostly university students. Therefore, it would be appropriate to consider more representative samples of communities (Frederick \& Fales, 2016), and to evaluate other moderating variables such as marital status (Gatzeva \& Paik, 2011), age (Dijkstra, Barelds, \& Groothof, 2010), existence of children or previous experience of infidelity (Zengel et al., 2013). It is advisable to replicate experimental design studies conducted with variables such as self-esteem (DeSteno et al., 2006), the status of the rival (Massar \& Bunn, 2016) and emoticons on Facebook (Hudson et al., 2015), inter alia. Moreover, $41 \%$ of the studies did not report the participants' sexual orientation, and this may be an important mediating variable (Dijkstra et al., 2013).

It is emphasized that there is a large number of instruments (about 40) which emphasize the evaluation of different components of the construct. Most have adequate levels of validity and reliability, albeit only a few feature confirmatory factor analysis in different samples (Martínez-León, Mathes, Avendaño, Peña, \& Sierra, in press). We suggest that the measurement include the results of research on stimuli that may evoke jealousy (Dijkstra et al., 2010), as well as on social situations that may incite more jealousy than others, such as "afternoon coffee vs. dinner invitation" (Kevin, Kniffin, \& Wansink, 2012), selfies (Halpem et al., 2017), features of the rival (Buunk et al., 2011) and social media monitoring (Dainton \& Stokes, 2015). Evaluation of romantic jealousy should be multimodal, integrating the results of scales, records, interviews with the partner, and nonverbal measures of emotional stress markers (DeSteno et al., 2006).

The review confirms that jealousy is not only affected by personal and interpersonal factors, but by more complex variables linked to the sociocultural environment. One of the personal variables - difference of sexes - in light of a situation of sexual or emotional infidelity, has for decades been the most controversial and studied variable. In this regard, each of the perspectives - both the evolutionary theory (Buss et al., 1992) and the cognitive social theory (Harris, 2003) - have received sufficient empirical support. Although the theory of "dual perspective" emerges in this divergence (DeSteno \& Salovey, 1996), it is important to include both methodologies -forced choice and continuous measures (Bendixen et al., 2015; Sagarin et al., 2012) - and to extend the studies to different cultures (Carpenter, 2012).

In this vein, the importance of assessing biological aspects is also evident, as is the case of the influence of the use of contraceptive pills (Cobey et al., 2013), the phase of the menstrual cycle (Cobey et al., 2012) and the 2:D 4:D ratio, prenatal exposure to testosterone (Bendixen et al., 2015.) in self-reporting jealousy. Similarly, prevalence of 
morbid jealousy was found in patients with Parkinson under dopaminergic therapy (Poletti et al., 2012) and in patients with brain damage (Kuruppuarachchi \& Seneviratne, 2011).

On the other hand-according to the results - selfesteem can be one of the major mediators of the jealousy response (DeSteno et al., 2006), as well as attachment, where there is consensus in that an anxious, fearful and insecure attachment may partly explain romantic jealousy (Belus et al., 2014). However, the results are inconclusive in other variables such as infatuation.

Romantic jealousy is an emotion awakened by a threat and generates a behavior of opposition to the threat, which is associated negatively to satisfaction in the relationship (Dandurand \& Lafontaine, 2014) depending on the type of jealousy (morbid), experiences of past infidelity (Stieglitz, Gurven, Kaplan, \& Winking, 2012) alcohol use (Dibello et al., 2014) and the context and response of the partner. In addition, romantic jealousy can lead to violence and fatal consequences (Harris, 2003). However, there are few studies on the response of the partner upon the manifestation of jealousy. It is known that the more amount of perceived affection in the relationship, the less jealous response (Goodboy, Horan, \& Booth-Butterfield, 2012). It would be interesting to include research conducted in the field of communications on the expression of jealousy towards the partner and the experience of uncertainty (Bevan, 2009; Pytlak, Zerega, \& Houser, 2015) as well as how the partner may be reinforcing the response of jealousy with their attention and approval.

The features of the rival that evoke this emotion are increasingly clearer, and it has been found at the transcultural level that there are similar characteristics of the rival causing jealousy, albeit more comparisons are to be made (Buunk \& Dijkstra, 2015). In addition, studies should be conducted on homosexual population (Dijkstra \& Buunk, 2002; Massar \& Buunk, 2010). Another key element is the analysis of the impact generated by social networks on romantic jealousy, as they constantly feed the interpersonal relationships of millions of people (Dainton \& Stokes, 2015). Facebook is the network which has the most studies in this regard (Cohen et al., 2014; Elphinston \& Noller, 2011), followed by Snapchat (Utz et al., 2015). However further studies with WhatsApp and Instagram - inter alia - are needed, as excess information - both registered and reported by others - changes the way we interact and our emotions in front of others.

In sum, this systematic review evinces that jealousy is a complex phenomenon which can be affected by many factors. Future studies with sufficient statistical robustness should achieve a clinical formulation indicating the relevance and predictive power of each of these factors, in order to shed light on issues pertaining to psychopathology and underlying hypotheses, in order to propose effective prevention dating violence and intervention strategies.

Finally, it should be noted that this study had limitations related to search criteria (the terms were limited to article titles) and only included scientific empirical articles published in English or Spanish on the topic of romantic jealousy.

\section{Appendix}

Attached in Teps website (www.teps.cl) is the list of 230 articles reviewed, including characteristics of the sample, instruments used to assess romantic jealousy and the main results.

\section{References}

Adams, H., \& Williams, L. (2014). "It's not just you two": A grounder theory of peer- influenced jealousy as a pathway to dating violence among acculturating Mexican American adolescents. Psychology of Violence, 4, 294-308. http://dx.doi.org/10.1037/a0034294

Alves, A., Pereira, M., Tieme, J., \& Otta, E. (2006). Emotional and sexual jealousy as a function of sex and sexual orientation in a Brazilian sample. Psychological Reports, 98, 529-535. http://dx.doi.org/10.2466/ PR0.98.2.529-535

American Psychiatric Association. (2013). Diagnostic and statistical manual of mental disorders (5th ed.). Washington D.C., United States: American Psychiatric Publishing

Barelds, D. P., \& Barelds-Dijkstra, P. B. (2007). Relations between different types of jealousy and self and partner perceptions of relationship quality. Clinical Psychology and Psychotherapy, 14, 176-188. http://dx.doi. org/10.1002/cpp.532

Bartholomew, K., \& Horowitz, L. M. (1991). Attachment styles among young adults: A test of a four-category Model. Journal of Personality and Social Psychology, 61, 226-244.

Belus, J. M., Wanklyn, S. G., Iverson, K. M., Pukay-Martin, N. D., Langhinrichsen-Rohling, J., \& Monson, C. (2014). Do anger and jealousy mediate the relationship between adult attachment styles and intimate violence perpetration?. Partner Abuse, 5, 388-406. http://dx.doi. org/10.1891/1946-6580.5.4.388

Bendixen, M., Kennair, L. E., \& Buss, D. M. (2015). Jealousy: Evidence of strong sex differences using both forced choice and continuous measure paradigms. Personality and Individual Differences, 86, 212-216.

Bevan, J. L. (2009). General partner and relational uncertainty as consequences of another person's jealousy expression. Western Journal of Communication, 68, 195-218. http://dx.doi.org/10.1080/10570310409374796

Block, C.R., \& Block, R. (2012). Margo Wilson's Contributions to the Chicago Homicide Dataset: Sexual rivalry and sexual jealousy. Homicide Studies, 16, 404-427. http://dx.doi.org/10.1177/1088767912461142

Brummen-Girigori, O., Buunk, A., Dijkstra, P., \& Girigori, A. (2016). Father abandonment and jealousy: A study among women on Curacao. Personality and Individual Differences, 96, 181-184. http://dx.doi. org/10.1016/j.paid.2016.02.048

Burchell, J., \& Ward, J. (2011). Sex drive, attachment style, relationship status and previous infidelity as predictors of sex differences in romantic jealousy. Personality and Individual Differences, 51, 657-661. http:// dx.doi.org/10.1016/j.paid.2011.06.002 
Buss, D., Larsen, R., \& Semmelroth, J. (1992). Sex differences in jealousy: Evolution, physiology, and psychology. Psychological Science, 3, 251255. http://dx.doi.org/10.1016/j.paid.2015.05.035

Buss, D., Shackelford, T., Kirkpatrick, L., Choe, J., Lim, H., Hasegawa, M., Hasegawa, T., \& Bennett, K. (1999). Jealousy and the nature of beliefs about infidelity: Tests of competing hypotheses about sex differences in the United States, Korea, and Japan. Personal Relationships, 6, 125-150. http://dx.doi.org/10.1111/j.1475-6811.1999.tb00215.x

Buunk, B. (1981). Jealousy in sexually open marriages, Alternative Lifestyles, 4, 357-372. http://dx.doi.org/10.1007/BF01257944

Buunk, B. (1982). Anticipated sexual jealousy: Its relationships to selfesteem, dependency and reciprocity. Personality and Social Psychology Bulletin, 8, 310-316

Buunk, A. (1997). Personality, birth order and attachment styles as related to various types of jealousy. Personality and Individual Differences, 22, 997-1006. http://dx.doi.org/ 10.1016/S0191-8869(97)00136-0

Buunk, A., Angleitner, A., Oubaid, V., \& Buss, D. (1996). Sex differences in jealousy in evolutionary and cultural perspective: Tests from the Netherlands, Germany and the United States. Psychological Science, 7, 359-363.

Buunk, A., Castro, A., Zurriaga, R., \& Gonzáles, P. (2011). Gender differences in the jealousy-evoking effect of rival characteristics: A study in Spain and Argentina. Journal of Cross-Cultural Psychology, 42, 323-339. http://dx.doi.org/10.1177/0022022111403664

Buunk, A., \& Dijkstra, P. (2015). Rival characteristics that provoke jealousy: A study in Iraqi Kurdistan. Evolutionary Behavioral Sciences, 9, 116-127. http://dx.doi.org/10.1037/ebs0000030

Buunk, A., Park, J., Zurriaga, R., Klavina, L., \& Massar, K. (2008). Height predicts jealousy differently for men and women. Evolution and Human Behavior, 29, 133-139. http://dx.doi.org/10.1016/j.evolhumbehav.2007.11.006

Buunk, B., \& Hupka, R. (1987). Cross cultural differences in the elicitation of sexual jealousy. Journal of Sex Research, 23, 12-22. http://dx.doi. org $/ 10.1080 / 00224498709551338$

Canto, J., Moscato, G., \& Moreno-Jiménez, P. (2010). Celos y sexismo: un estudio comparativo entre una muestra española y una muestra cubana. Revista de Psicología Social, 26, 33-43. http://dx.doi. org/10.1174/021347411794078480

Carpenter, C. J. (2012). Meta-analyses of sex differences in responses to sexual versus emotional infidelity: Men and women are more similar than different. Psychology of Women Quarterly, 36, 25-37. http://dx.doi. org/10.1177/0361684311414537

Clanton, G. (1996). A sociology of jealousy. International Journal of Sociology and Social Police, 16, 171-189. http://dx.doi.org/10.1108/eb013274

Cobey, K., Buunk, A., Roberts, C., Klipping, N., Appels, N., Zimmerman, Y., Coelingh, H., \& Pollet, T. (2012). Reported jealousy differs as a function of menstrual cycle stage and contraceptive pill use: A withinsubjects investigation. Evolution and Human Behavior, 33, 395-401. http://dx.doi.org/10.1016/j.evolhumbehav.2011.12.001

Cobey, K., Roberts, C., \& Buunk, A. (2013). Hormonal contraceptive congruency: Implications for relationship jealousy. Personality and Individual Differences, 55, 569-573. http://dx.doi.org/10.1016/j. paid.2013.04.031

Cohen, E., Bowman, N., \& Borchert, K. (2014). Private flirts, public friends: Understanding romantic jealousy responses to an ambiguous social network site message as a function of message access exclusivity. Computers in Human Behavior, 35, 535-541. http://dx.doi.org/10.1016/j. paid.2015.04.003

Cortés-Ayala, L., Flores, M., Bringas, C., Rodríguez-Franco, L., LópezCepero, J., \& Rodríguez, F. J. (2015). Relación de maltrato en el noviazgo de jóvenes mexicanos. Análisis diferencial por sexo y nivel de estudios. Terapia Psicológica, 33, 5-12.

Croucher, S., Homsey, D., Guarino, L., Bohlin, B., Trumpetto, J., Izzo, A., Huy, A., \& Sykes, T. (2012). Jealousy in four nations: A cross-cultural analysis. Communication Research Reports, 29, 353-360. http://dx.doi. org/10.1080/08824096.2012.723273

Dainton, M., \& Stokes, A. (2015). College students' romantic relationships on Facebook: Linking the gratification for maintenance to Facebook maintenance activity and the experience of jealousy. Communication Quarterly, 63, 365-383. http://dx.doi.org/10.1080/01463373.2015.1 058283

Dandurand, C., \& Lafontaine, M. (2014). Jealousy and couple satisfaction: A romantic attachment perspective. Marriage \& Family Review, 50, 154-173. http://dx.doi.org/10.1080/01494929.2013.879549

De Silva, P. (1997). Jeaolousy in couple relationships: Nature, assessment and therapy. Behaviour Research and Therapy, 35, 973-985. http:// dx.doi.org/10.1016/S0005-7967 (97)00051-X

DeSteno, D., Barlett, M., Braverman, J., \& Salovey, P. (2002). Sex differences in jealousy: Evolutionary mechanism or artifact of measurement? Journal of Personality and Social Psychology, 83, 1103-1116. http:// dx.doi.org/10.1037/0022-3514.83.5.1103

DeSteno, D., \& Salovey, P. (1996). Evolutionary origins of sex differences in jealousy? Questionin the "fitness" of the model. Psychological Science, 7, 267-372. http://dx.doi.org/10.1111/j.1467-9280.1996.tb00391.x

DeSteno, D., Valdesolo, P., \& Barlett, M. (2006). Jealousy and the threatened self: Getting to the heart of the green-eyed monster. Journal of Personality and Social Psychology, 91, 626-641. http://dx.doi. org/10.1037/0022-3514.91.4.626

Dibello, A., Neighbors, C., Rodriguez, L., \& Lindgren, K. (2014). Coping with jealousy: The association between maladaptive aspects of jealousy and drinking problems is mediated by drinking to cope. Addictive Behaviors, 39, 94-100. http://dx.doi.org/10.1016/j.addbeh.2013.08.032

DiBello, A., Rodríguez, L., Hadden, B., \& Neighbors, C. (2015). The green eyed monster in the bottler: Relationship contingent self-esteem, romantic jealousy, and alcohol-related problems. Addictive Behaviors, 49, 52-48. http://dx.doi.org/10.1016/j.addbeh.2015.05.008

Dijkstra, P., Barelds, D., \& Groothof, H. (2010). An inventory and update of jealousy-evoking partner behaviors in modern society. Clinical Psychology and Psychotherapy, 17, 329-345. http://dx.doi.org/10.1002/cpp.668

Dijkstra, P., Barelds, D., \& Groothof, H. (2013). Jealousy in response to online and offline infidelity: The role of sex and sexual orientation. Scandinavian Journal of Psychology, 54, 328-36. http://dx.doi. org/10.1111/sjop. 12055

Dijkstra, P., \& Buunk, B. (2002). Sex differences in the jealousy-evoking effect of rival characteristics. European Journal of Social Psychology, 32, 829-852. http://dx.doi.org/10.1002/ejsp. 125

Easton, J. A., \& Shackelford, T. K. (2009). Morbid Jealousy and sex differences in partner-directed violence. Human Nature, 20, 342-350. http://dx.doi.org/10.1007/s12110-009-9069-1

Edlund, J. E., Heider, J. D., Sherer, C. R., Farc, M. M., \& Sagarin, B. J. (2006). Sex differences in jealousy in response to actual infidelity. Evolutionary Psychology, 4, 462-470. http://dx.doi. org/10.1177/147470490600400137

Elphinston, R. A., \& Noller, P. (2011). Time to face it! Facebook instrusion and the implications for romantic jealousy and relationship. CyberPsychology Behavior and Social Networking, 14, 631-635. http://dx.doi. org/10.1089/cyber.2010.0318

Fernández, A. M., Sierra, J. C., Zubeidat, I., \& Vera-Villarroel P. (2006). Sex differences in response to sexual and emotional infidelity among Spanish and Chilean students. Journal of Cross-Cultural Psychology, $37,359-365$.

Foran, H. M., \& O'leary, K. D. (2008). Problem drinking, jealousy, and anger control: Variables predicting physical aggression against a partner. Journal of Family Violence, 23, 141-148. http://dx.doi.org/10.1007/ s10896-007-9136-5

Frederick, D., \& Fales, M. (2016). Upset over sexual versus emotional infidelity among gay, lesbian, bisexual, and heterosexual adults. Archives of Sexual Behavior, 45, 175-191. http://dx.doi.org/10.1007/s10508014-0409-9

Fussell, N., Rowe, A., \& Park, J. (2011). Masculinized brain and romantic jealousy: Examining the association between digit ratio (2D:4D) and between- and within-sex differences. Personality and Individual Differences, 51, 107-111. http://dx.doi.org/10.1016/j.paid.2011.03.020

Gatzeva, M., \& Paik, A. (2011). Emotional and physical satisfaction in noncohabiting, cohabiting, and marital relationships: The importance 
of jealous conflict. Journal of Sex Research, 48, 29-42. http://dx.doi. org/10.1080/00224490903370602

Geary, D., Rumsey, M., Bow-Thomas, C., \& Hoard, M. (1995). Sexual jealousy as a facultative trait: Evidence from the pattern of sex differences in adults from China and the United States. Ethology and Sociobiology, 16, 355-383. http://dx.doi.org/10.1016/0162-3095 (95)00057-7

Goodboy, A., Horan, S., \& Booth-Butterfield, M. (2012). Intentional jealousy-evoking behavior in romantic relationships as a function of received partner affection and love styles. Communication Quartely, 60, 370. http://dx.doi.org/10.1080/01463373.2012.688792

Green, M., \& Sabini, J. (2006). Gender, socioeconomic status, age, and jealousy: Emotional responses to infidelity in national sample. Emotion, 6, 330-334. http://dx.doi.org/10.1037/1528-3542.6.2.330

Halpem, D., Katz, J. E., \& Carril, C. (2017). The online ideal persona vs. the jealousy effect: Two explanations of why selfies are associated with lower-quality romantic relationships. Telematics and Informatics, 34, 114-123. http://dx.doi.org/10.1016/j.tele.2016.04.014

Harris, C. (2003). A review of sex differences in sexual jealousy, including self-report data, psychophysiological responses, interpersonal violence, and morbid jealousy. Personality and Social Psychology Review, 7, 102-128. http://dx.doi.org/10.1207/S15327957PSPR0702_102-128

Harris, C. R. (2000). Psychophysiological responses to imagined infidelity: The specific innate modular view of jealousy reconsidered. Journal of Personality and Social Psychology, 78, 1082-1091. http://dx.doi. org/10.1037/0022-3514.78.6.1082

Hart, S. L., \& Legerstee, M. (2013). Handbook of jealousy: Theory, research, and multidisciplinary approaches. Londres: Wiley-Blackell

Hudson, M., Nicolas, S., Howser, M., Lipsett, K., Robinson, I., Pope, L., Hobby, A., \& Friedman, D. (2015). Examining how gender and emoticons influence Facebook jealousy. Cyberpsychology, Behavior, and Social Networking, 18, 87-92. http://dx.doi.org/10.1089/cyber.2014.0129.

Hupka, R., \& Zaleski, Z. (1990). Romantic jealousy and romantic envy in Germany, Poland, and the United States. Behavior Science Research, 24, 17-28. http://dx.doi.org/10.1177/106939719002400102

Kar, H., \& O'Leary, D. (2013). Patterns of psychological aggression, dominance, and jealousy within marriage. Journal of Family Violence, 28, 109-119. http://dx.doi.org/10.1007/s10896-012-9492-7

Kevin, M. Kniffin, K. M., \& Wansink, B. (2012). It's not just lunch: Extrapair commensality can trigger sexual jealousy. Plos One ,7, 1-4. http:// dx.doi.org/10.1371/journal.pone. 0040445

Khanchandani, L., \& Durham, T. (2009). Jealousy during dating among female college students. College Student Journal, 43, 1272-1278. http:// dx.doi.org/10.1007/BF00287865

Kuruppuarachchi, K. A., \& Seneviratne, A. (2011). Organic causation of morbid jealousy. Asian Journal of Psychiatry, 4, 528-260. http://dx.doi. org/10.1016/j.ajp.2011.09.003

Leary, M. R., Tambor, E. S., Terdal, S. K., \& Downs, D. (1995). Selfesteem as an interpersonal monitor: The sociometer hypothesis. Journal of Personality and Social Psychology, 68, 518-530.

Llor-Esteban, B., García-Jiménez, J. J., Ruiz-Hernández, J. A., \& GodoyFernández, C. (2016). Profile of partner aggressors as a function of risk of recivism. International Journal of Clinical and Health Psychology, 16, 39-46. http://dx.doi.org/10.1016/j.ijchp.2015.05.004

López-Ossorio, J. J., González Álvarez, J. L., Buquerín Pascual, S., García, L. F., \& Buela-Casal, G. (2017). Risk factors related to intimate partner violence pólice recidivism in Spain. International Journal of Clinical and Health Psychology, 17, 107-119. http://dx.doi.org/10.1016/j. ijchp.2016.12.001

Martínez-León, N. C., Mathes, E. W., Avendaño, B.L., Peña, J. J. y Sierra, J. C. (in press). Psychometric Study of the Interpersonal Jealousy Scale in Colombian Samples. Revista Latinoamericana de Psicología.

Massar, K., \& Buunk, A. (2010). Judging a book by its cover: jealousy after subliminal priming with attractive and unattractive faces. Personality and Individual Differences, 49, 634-638. http://dx.doi.org/10.1016/j. paid.2010.05.037

Massar, K., \& Buunk, A. (2016). Individual differences in preventive jealousy determine men's jealousy after subliminal exposure to rivals wearing high or low-status clothes. Psychological Reports, 118, 219235. http://dx.doi.org/10.1177/0033294115625572

Mathes, E. W. (1986). Jealousy and romantic love: A longitudinal study. Psychological Reports, 58, 885-886. http://dx.doi.org/10.2466/ pr0.1986.58.3.885

Mathes, E. W. (1992). Jealousy: The psychological data. New York, NY: University Press of America.

Mathes, E. W., Roter, P., \& Joerger, S. (1982). A convergent validity study of six jealousy scales. Psychological Reports, 50, 1143-1147. http:// dx.doi.org/10.2466/pr0.1982.50.3c.1143

Mathes, E.W., \& Severa, N. (1981). Jealousy, romantic love, and liking: Theoretical considerations and preliminary scale development. Psychological Reports, 49, 23-31. http://dx.doi.org/10.2466/pr0.1981.49.1.23

McAndrew, F., \& Shah, S. (2013). Sex differences in jealousy over Facebook activity. Computers in Human Behavior, 29, 2603-2606. http:// dx.doi.org/10.1016/j.chb.2013.06.030

Mcintosh, E. (1989). An investigation of romantic jealousy among black undergraduates. Social Behavior and Personality, 17, 135-142. https:// doi.org/10.2224/sbp.1989.17.2.135

Miller, M., Denes, A., Diaz, B., \& Buck, R. (2014). Attachment Style Predicts Jealous Reactions to viewing touch between a Romantic Partner and close friend: Implications for internet social communication. Journal of Nonverbal Behavior, 38, 451-476. http://dx.doi.org/10.1007/ s10919-014-0196-y

Montero, I., \& León, O. (2007). A guide for naming research studies in psychology. International Journal of Clinical and Health Psychology, $7,847-862$.

Muise, A., Christofides, E., \& Desmarais, S. (2009). More information than you wanted: Does facebook bring out the green-eyed monster of jealousy? CyberPsychology \& Behavior, 13, 441-444. http://dx.doi. org $/ 10.1089 / \mathrm{cpb} .2008 .0263$

Muise, A., Christofides, E., \& Desmarais, S. (2014). "Creeping” or just information seeking? Gender differences in partner monitoring in response to jealousy on Facebook. Personal Relationships, 21, 35-50. http://dx.doi.org/10.1111/pere.12014

Mužinié, L., Miroslav, G., Jukié, V., Dordevié, V., Koié, E., \& Herceg, M. (2003). Forensic importance of jeaolusy. Collegium Antropologicum, 27, 293-300.

O'Connor, J., \& Feinberg, D. (2012). The influence of facial masculinity and voice pitch on jealousy and perceptions of intrasexual rivarly. Personality and Individual Differences, 52, 369-373. http://dx.doi. org/10.1016/j.paid.2011.10.036

Orosz, G., Zoltán, G., Kiss, Z. G., Farkas, P., \& Roland-Lévy, K. (2015). Elevated romantic love and jealousy if relationship status is declared on Facebook. Frontiers in Psychology, 6, 1-6. http://dx.doi.org/10.3389/ fpsyg.2015.00214

Osamu, K. (2016). Becoming a psychoanalyst: To think about the nature of jealousy. Psychoanalytic Inquiry, 36, 162-170. http://dx.doi.org/10 $.1080 / 07351690.201 .1123999$

Ottesen, L., Nordeide, J., Andreaseen, S., Stronen, J., \& Pallesen, S. (2011). Sex differences in jealousy: A study form Norway. Nordic Psychology, 63, 20-34. http://dx.doi.org/10.1027/1901-2276/a000025

Perestelo-Perez, L. (2013). Standards on how to develop and report systematic reviews in Psychology and Health. International Journal of Clinical and Health Psychology, 13, 49-57. http://dx.doi.org/10.1016/ S1697-2600 (13)70007-3

Pfeiffer, S. M., \& Wong, P. T. (1989). Multidimensional jealousy. Journal of Social and Personal Relationships, 6, 181-196. http://dx.doi. org $/ 10.1177 / 026540758900600203$

Pines, A. M. (1992). Romantic jealousy: Five perspectives and an integrative approach. Psychotherapy, 29, 675-683. http://dx.doi. org/10.1037/0033-3204.29.4.675

Poletti, M., Perugi, G., Logi, Ch., Romano, A., Del Dotto, P., Ceravolo, R., \& Bonucelli, U. (2012). Dopamine agonists and delusional jealousy in Parkinson's disease: A cross-sectional prevalence study. Movement Disorders, 27, 1679-1682. http://dx.doi.org/10.1002/mds.25129

Pytlak, M. A., Zerega, L. M., \& Houser, M. L. (2015). Jealousy evocation: Understanding commitment, satisfaction, and uncertainty as predictors 
of jealousy-evoking behaviors. Communication Quarterly, 63, 310-328 http://dx.doi.org/10.1080/01463373.2015.1039716

Rauer, A. J., \& Volling, B. L. (2007). Differential parenting and sibling jealousy: Developmental correlates of young adults romantic relationships. Personal Relationships, 14, 495-511. http://dx.doi.org/10.1111/j.14756811.2007.00168.x

Retana, B. E., \& Sánchez, R. (2008). El papel de los estilos de apego y los celos en la asociación con el amor adictivo. Psicología Iberoamericana, 16, 15-22.

Rodríguez, L., DiBello, A., \& Neighbors, C. (2015). Positive and negative jealousy in the association between problem drinking and IPV perpetration. Journal of Family Violence, 30, 987-997. http://dx.doi. org/10.1007/s10896-015-9736-4

Rodríguez, L., DiBello, A., Overup, C., \& Neighbors, C. (2015). The Price of distrust: trust, anxious attachment, jealousy, and partner abuse. Partner Abuse, 6, 298-319.

Rubin, Z. (1970). Measurement of romantic love. Journal of Personality and Social Psychology, 16, 265-273. http://dx.doi.org/10.1037/ h0029841

Sagarin, B. J., Martin, A. L., Coutinho, S. A., Edlund, J. E., Patel, L., Skowronski, J. J., \& Zengel, B. (2012). Sex differences in jealousy: A meta-analytic examination. Evolution and Human Behavior, 33, 595614. http://dx.doi.org/10.1016/j.evolhumbehav.2012.02.006

Salovey, P. (1991). The psychology of jealousy and envy. New York, NY: The Gilford Press.

Salovey, P., \& Rodin, J. (1991). Provoking jealousy and envy: Domain relevance and self-esteem threat. Journal of Social and Clinical Psychology, 10, 395-413. http://dx.doi.org/10.1521/jscp.1991.10.4.395

Sánchez, R. (2009). Efectos diferenciales del bienestar subjetivo, autorrealización y celos en las fases del amor pasional. Enseñanza e Investigación en Psicología, 14, 5-21.

Scherer, C., Akers, E., \& Kolbe, K. (2013). Bisexuals and the sex differences in jealousy hypothesis. Journal of Social and Personal Relationships, 30,1064. http://dx.doi.org/10.1177/0265407513481446

Schützwohl, A. (2005). Sex differences in jealousy: the processing of cues to infidelity. Evolution and Human Behavior, 26, 288-299. http://dx.doi. org/10.1016/j.evolhumbehav.2004.09.003

Sharpsteen, D., \& Kirkpatrick, L. (1997). Romantic jealousy and adult romantic attachment. Journal of Personality and Social Psychology, 72, 627-640. http://dx.doi.org/10.1037//0022-3514.72.3.627

Soyka, M., Naber, G., \& Volcker, A. (1991). Prevalence of delusional jealousy in different psychiatric disorders: An analysis of 93 cases. British Journal of Psychiatry, 158, 549-553. http://dx.doi.org/10.1192/ bjp.158.4.549

Stieger, S., Preyss, A., \& Voracek, M. (2012). Romantic jealousy and implicit and explicit self-esteem. Personality and Individual Differences, 32, 51-55. http://dx.doi.org/10.1016/j.paid.2011.08.028

Stieglitz, J., Gurven, M., Kaplan, H., \& Winking, J. (2012). Infidelity, jealousy, and wife abuse among Tsimane forager- farmers: Testing evolutionary hypotheses of marital conflict. Evolution and Human Behavior 33, 438- 448. http://dx.doi.org/10.1016/j.evolhumbehav.2011.12.006

Strawhun, J., Adams, N., \& Huss, M. (2013). The assessment of cyberstalking: An expanded examination including social networking, attachment, jealousy, and anger in relation to violence and abuse. Violence and Victims, 28, 715-730. http://dx.doi.org/10.1891/0886-6708.11-00145

Swami, V., Inamdar, S., Stieger, S., Nader, I., Pietschnig, J., Tran, U., \& Voracek, M. (2012). A dark side of positive illusions? Associations between the love-is-blind and the experience of jealousy. Personality and Individual Differences, 53, 796-800. http://dx.doi.org/10.1016/j. paid.2012.06.004

Tagler, M. (2010). Sex differences in jealousy: Comparing the influence of previous infidelity among college students and adults. Social Psychological Personality Science, 1, 353-360. http://dx.doi. org/10.1177/1948550610374367

Ureña, J., Romera, E. M., Casas, J. A., Viejo, C., \& Ortega-Ruiz, R. (2015). Psychometric properties of Psychological Dating Violence Questionnaire: A study with Young couples. International Journal of Clinical and Health Psychology, 15, 52-60. http://dx.doi.org/10.1016/j.ijchp.2014.07.002
Utz, S., Muscanell, N., \& Khalid, C. (2015). Snapchat elicits more jealousy than Facebook: A comparison of Snapchat and Facebook use. Cyberpsychology, Behavior, and Social Networking, 18, 141-146. http://dx.doi. org/10.1089/cyber.2014.0479

Wang, T., Parish, W., Laumann, E., \& Luo, Y. (2009). Partner violence and sexual jealousy in china: A population-based survey. Violence Against Women, 15, 774-798. http://dx.doi.org/10.1177/1077801209334271

White, G. (1981). Jealousy and partner's perceived motives for attraction to a rival. Social Psychology Quarterly, 44, 24-30.

White, G. L. (1984). Comparison of four jealousy scales. Journal of Research in Personality, 18, 115-130. http://dx.doi.org /10.1016/0092-6566 (84) $90024-2$

Zandbergen, D., \& Brown, S. G. (2015). Cultural and gender differences in romantic jealousy. Personality and Individual Differences, 72, 122-127. http://dx.doi.org/10.1016/j.paid.2014.08.035

Zengel, B., Edlund, J. E., \& Sagarin, B. (2013). Sex differences in jealousy in response to infidelity: Evaluation of demographic moderators in a national random sample. Personality and Individual Differences, 54, 47-51. http://dx.doi.org/10.1016/j.paid.2012.08.001 